
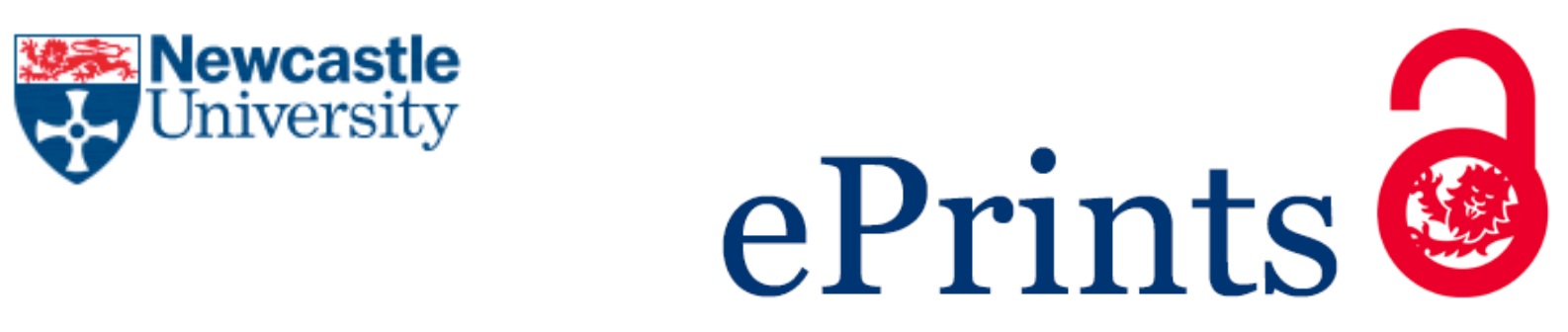

\title{
Corcoran S.
}

Roman law and the two languages in Justinian's empire. Bulletin of the Institute of Classical Studies 2017, 60(1), 96-116

\section{Copyright:}

This is the peer reviewed version of the following article: Corcoran S. Roman law and the two languages in Justinian's empire. Bulletin of the Institute of Classical Studies 2017, 60(1), 96-116, which has been published in final form at http://doi.org/10.1111/2041-5370.12049. This article may be used for noncommercial purposes in accordance with Wiley Terms and Conditions for Self-Archiving.

DOI link to article:

http://doi.org/10.1111/2041-5370.12049

Date deposited:

$22 / 04 / 2017$

Embargo release date:

19 June 2019 


\section{ROMAN LAW AND THE TWO LANGUAGES IN JUSTINIAN'S EMPIRE SIMON CORCORAN}

Fergus Millar's direction and encouragement as my thesis supervisor are clearly imprinted within the resulting book, The Empire of the Tetrarchs, influenced by his view of Roman imperial government, especially the classic concept of 'petition and response'. This concept I have restated in emphatic fashion in a chapter dedicated to Fergus in 2014. ${ }^{2}$ The current paper, therefore, does not revisit this shared intellectual past, but explores newer areas of coincidence, where my engagement with the works of Roman law in late antiquity and the early Middle Ages, especially under the aegis of the Projet Volterra ${ }^{3}$ has developed in the context of other and more recent work by Fergus on cultural and linguistic diversity in the eastern portion of the Roman Empire. ${ }^{4}$

Latin was the original language of Roman law. Greek was the default language of administration in Rome's eastern territories, as well as the prestige language of high culture. Latin and Greek coexisted in the East from the moment the Romans arrived there, and the problems of rendering official Latin into Greek had to be faced very early. ${ }^{5}$ Consider, for instance, the bilingual version of the treaty with Cibyra dating to $174 \mathrm{BC}$, of which significant new fragments have been found in the last few years. ${ }^{6}$ For Roman citizens using Roman law, of course, certain formal documents needed to be in Latin. Oral procedures came to be less strict, especially for aspects of law regarded as deriving

\footnotetext{
${ }^{1}$ S. Corcoran, The Empire of the Tetrarchs: Imperial Pronouncements and Government AD 284-324 (Oxford 1996; rev. ed. 2000). The principal inspiration was F. G. B. Millar, The Emperor in the Roman World 31 BC-AD 337 (London 1977; rev. ed. 1992).

${ }^{2} \mathrm{~S}$. Corcoran, 'State correspondence in the Roman Empire: imperial communication from Augustus to Justinian', in State Correspondence in the Ancient World from New Kingdom Egypt to the Roman Empire, ed. K. Radner (New York 2014) 172-209.

${ }^{3}$ https://www.ucl.ac.uk/volterra. See also S. Corcoran, 'An introduction to the Projet Volterra', BICS 49 (2006) 215-19.

${ }^{4}$ Notably A Greek Roman Empire: Power and Belief under Theodosius II 408-450 (Berkeley et al. 2006); Religion, Language, and Community in the Roman Near East: Constantine to Muhammad (Oxford 2014); Empire, Church, and Society in the Late Roman Near East (Leuven 2015).

${ }^{5}$ For a wide-ranging set of essays on Roman legal language down to late antiquity, see Modelli di un multiculturalismo giuridico: il bilinguismo nel mondo antico, eds C. Cascione et al., 2 vols (Naples 2013); cf. C. Masi Doria, Modelli giuridici, prassi di scambio e medium linguistico (Naples 2012).

${ }^{6}$ I. Kibyra 1 (formerly OGIS 762) with new fragments, including some Latin, to be published by Ludwig Meier; brief report in Ş. Özüdoğru, 'An interpretation of the new evidence concerning Hellenistic Cibyra', Cedrus 2 (2014) 171-88 (177-79) [in Turkish]. For analysis of other later Republican and early imperial documents, see U. Laffi, In greco per i Greci (Pavia 2013).
} 
from the ius gentium. Thus it was accepted that oral stipulations, the most flexible tool for contracts, could be made in Greek, or indeed any language. ${ }^{7}$ But as citizenship spread, and the most formal procedures became obsolete, the role of Greek expanded. The key moment is the Constitutio Antoniniana of AD 212. It is no surprise that, following this, Severus Alexander should have ruled that wills could be made in Greek. ${ }^{8}$ Yet developments for the everyday did not yet affect the role of Latin at the highest levels. While the emperor could write officially in Greek to Greek speakers, the most formal legislation remained in Latin, as did correspondence within the higher administration. The normative texts of the law remained in Latin. This world is well delineated in $A$ Greek Roman Empire. ${ }^{9}$ My aim here is to move a century ahead to the reign of Justinian and to consider the relationship of Latin and Greek, the two languages in the law of his empire. In particular, I would like to ask the question: when could a lawyer practise effectively without knowing Latin?

In February 528 Justinian wrote to the Senate in Constantinople describing a plan for a new code of imperial constitutions $(C J C . H a e c)$, which was at once to subsume and to supersede the three pre-existing collections, the Gregorian, Hermogenian, and Theodosian, as well as subsequent laws, including those of Justinian himself. ${ }^{10} \mathrm{He}$ endowed a commission of officials and lawyers with extensive editorial powers for changing and arranging the material. Just over a year later (April 529) their labours bore fruit in a code in twelve books (CJ C. Summa). This seems to have been a project for a new reign, complete in itself. Four hundred years of legislation by Justinian's predecessors had been constrained into a harmonized whole sheltering under the aegis of his name - practicality and propaganda all in one. Ecclesiastical policy was also made

\footnotetext{
${ }^{7}$ Gai. Inst. 3.93-94 and Ulp. Dig. 45.1.1.6; cf. testamentary trusts (fideicommissa): Gai. Inst. 2.281; Ulp. Dig. 32.11.pr. On stipulations, see A. Wacke, 'Gallico aut Germanico sermo stipulari? L'uso delle lingue straniere secondo il ius gentium romano' and A. Cusmà Piccione, 'D. 45.1.1.6 (Ulp. 48 ad Sab.): lingue straniere e conceptio verborum della stipulatio nella prospettiva di Ulpiano', both in Modelli di un multiculturalismo giuridico (n. 5, above) 87-118 and 339-436.

${ }^{8}$ SB I 5294 (Stud. Pal. XX 35) with Nov. Theod. 16.8; B. Rochette, 'La langue des testaments dans l'Égypte du III 's. ap. J.-C.', RIDA 47 (2000) 449-61; M. Nowak, 'Titius heres esto!', JJP 40 (2010) 16184 (162-64) and Wills in the Roman Empire: A Documentary Approach (Warsaw 2015) 108-12.

${ }^{9}$ Millar, Greek Roman Empire (n. 4, above), especially 7-23.

${ }^{10}$ For summary accounts of Justinian's codification, see W. Kaiser, 'Justinian and the Corpus Iuris Civilis', in The Cambridge Companion to Roman Law, ed. D. Johnston (New York 2015) 123-26 and S. Corcoran, 'The Codex of Justinian; the life of a text through 1,500 years', in The Codex of Justinian, ed. B. Frier, 3 vols (Cambridge 2016) I xcviii-ci.
} 
plain, through the relocation of religious material to prominence at the beginning of the Code, with the inclusion also of texts emphasizing Chalcedonian orthodoxy (CJ 1.1.4-7).

The following summer, the emperor's chief legal officer, the quaestor Thomas, was dismissed under suspicion of crypto-paganism. He was replaced by a former colleague on the Code commission, Tribonian, who, with the acumen and obsession of a professional, quickly came to focus on the writings of the classical jurists, which formed an extensive, if unevenly utilized, jumble. ${ }^{11}$ Previously, in an attempt at manageability, five jurists (Papinian, Paul, Gaius, Ulpian, and Modestinus), plus those others they vicariously cited, had been granted privileged status in court on the basis of a fragment of a Western law of 426 (called by scholars the 'Law of Citations'), edited successively into the Theodosian and new Justinian Codes. ${ }^{12}$ Tribonian now went further. First he settled numerous ancient differences of opinion by means of a series of rulings (later called the Fifty Decisions) issued by Justinian in 530-531. ${ }^{13}$ Even before these were completed, in December 530 he wrote, in Justinian's name, a long constitution addressed to himself setting out in detail an ambitious project to gather and reduce into a 'nutshell' the classical juristic writings from the period between Augustus and Diocletian, in the process transforming them into a single systematized, internally consistent, and up-todate compendium (Digest $C$. Deo Auctore [=CJ 1.17.1]). For three years a large commission was at work, unaffected even by the Nika Riot at Constantinople (January 532), a serious revolt that almost ended Justinian's rule. ${ }^{14}$ Although this saw the sacking as quaestor of a scapegoated Tribonian, he was not removed from management of the

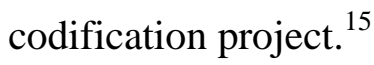

The product of this labour was the Digest, which, comprising fifty books, was a substantial work, if only a fraction of its mass of sources. Extracts from the jurists were

\footnotetext{
${ }^{11}$ On Tribonian, see T. Honoré, Tribonian (London 1978).

${ }^{12}$ CTh 1.4.3; CJ 1.15.1 (P. Oxy. XV 1814); T. Honoré, Law in the Crisis of Empire (Oxford 1998) 24951; J. F. Matthews, Laying Down the Law (New Haven - London 2000) 24-25; S. Corcoran, 'Justinian and his two codes: revisiting P. Oxy. 1814', JJP 38 (2008) 73-111 (96-98).

${ }^{13}$ C. Russo Ruggeri, Studi sulle Quinquaginta Decisiones (Milan 1999) and 'Sulle quinquaginta decisiones dieci anni dopo', SDHI 76 (2010) 445-67; H. Weber, 'A hypothesis regarding Justinian's decisiones and the Digest', Roman Legal Tradition 11 (2015) 42-117.

${ }^{14}$ G. Greatrex, 'The Nika Riot: a reappraisal', JHS 117 (1997) 60-86; H. Leppin, Justinian: Das christliche Experiment (Stuttgart 2011) 142-48.

${ }^{15}$ Procop. Bell. 1.24.11-18. On completion of the codification, Tribonian became quaestor again in 535. Honoré, Tribonian (n. 11, above) 56-58.
} 
assembled under suitable titles, weighted (at some forty per cent) towards the writings of Ulpian (d. 223). ${ }^{16}$ Simultaneously there appeared the Institutes, a short four-book work, adapted jointly from the Institutes of Gaius by Tribonian with Theophilus and Dorotheus (both law professors), designed as the new first year law school textbook. The two works came into force on 30 December 533 (Digest C. Tanta [= CJ 1.17.2]; Just. Inst. $C$. Imperatoriam Maiestatem), thereby rendering obsolete all the earlier output of the jurists.

These works now made the 'new' Code of 529 rather out of date. Therefore Justinian commanded that the intervening legislation, including the Fifty Decisions, be edited into the Code, whose existing text was pruned or altered to reflect these recent changes. Thus in November 534 a revised edition of the Code, the Codex repetitae praelectionis, was promulgated (CJ C. Cordi). When it came into force on 29 December, the Justinianic codification of Roman law was completed.

Codification was not an entirely new concept at Rome. The idea of gathering the law, or at least some of the law, into a fixed form, at once subsuming and superseding what had gone before, can be found not only in the project of Theodosius II, but with the Praetor's Edict under Hadrian, the stalled ambitions of Julius Caesar, or even as far back as the Twelve Tables. Justinian's codification, however, was breathtaking in its ambition and execution, because he codified all the law, sweeping away everything that existed previously. Theodosius's not dissimilar plan had never progressed beyond his Code, conceived as a substantial Vorarbeit for a more extensive, but unrealized project (CTh 1.1.5-6. Theod. Nov. 1). ${ }^{17}$ The Breviary of the Visigothic king Alaric II, issued in 506, was also more limited. ${ }^{18}$ Justinian and his advisers were perhaps unaware of Alaric's Code and would no doubt have dismissed it as a barbarous and heretic parody, even if they had known about it. But Theodosius's plan would have been known to them, even though Justinian never picked out Theodosius by name among those imperial predecessors whom he had the daring to supersede. ${ }^{19}$

\footnotetext{
${ }^{16}$ On the editorial process, see T. Honoré, Justinian's Digest: Character and Compilation (Oxford 2010).

${ }^{17}$ Matthews, Laying Down the Law (n. 12, above) 58-60.

${ }^{18}$ K. Zeumer, Leges Visigothorum (MGH Legum 1.1; Hanover 1902) 465-67 (commonitorium Alarici); J. Gaudemet, Le Bréviaire d'Alaric et les epitomes (Milan 1965) [repr. in La formation du droit canonique médiéval (London 1980) ch. I]; Le Bréviaire d'Alaric. Aux origines du Code civil, ed. M. Rouche and B. Dumézil (Paris 2009).

${ }^{19}$ See the sentiments of daring and impossibility at CJ C. Haec. pr. and Digest C. Deo Auctore 2.
} 
The codification, therefore, became all that mattered in terms of the world of Roman law after 534, or at least created a fresh starting point. To what extent was this corpus a bilingual product? Did one need equal fluency in Latin and Greek to make use of it? First, it must be stated that the majority of the texts contained in the corpus were in Latin. The Institutes contained virtually no Greek, the most extensive being a couple of quotations from Homer amounting to a dozen lines. ${ }^{20}$ The Digest contained only a little more. The jurists had occasionally quoted classical authors (Homer, Demosthenes) ${ }^{21}$ or an imperial rescript, ${ }^{22}$ but the most extensive Greek came from the few works actually written originally in Greek. The most significant of these was the Excusationes of Modestinus, a work easily seen as a third-century response to the extended citizenship of the Constitutio Antoniniana. ${ }^{23}$ With so many new citizens in the East, there had been an obvious need for an accessible guide to the often onerous duties of tutela and the ways to avoid them. Thus Modestinus himself says in his opening address to Egnatius Dexter, 'I shall do what I can to make the exposition of the problems clear, translating technical terms into Greek, although I know that such translation is not particularly suitable. ${ }^{24}$ Modestinus was a high-status author, who earned a place among the 'Mighty Handful' of authoritative jurists canonized in the Law of Citations. Even so, he represents almost the final generation of classical jurists, so that such new writing in Greek was in its infancy with a legal terminology rapidly evolving even as the genre itself went into eclipse, existing texts becoming canonized with a mixture of ossification and pseudonymous refashioning. ${ }^{25}$ Therefore the number of these works in Greek, which acquired classic status and so provided source material for the Digest, was quite limited.

\footnotetext{
${ }^{20}$ Inst. 3.23.2, 4.3.1. On Inst. 2.7.1, where the Greek is missing in the manuscripts, see J. H. A. Lokin, 'Dormitat bonus Homerus in I. 2, 7, 1', in Mélanges Felix Wubbe, eds J. A. Ankum et al. (Freiburg 1993) 295-99 (repr. Analecta Groningana [Groningen 2010] 151-54).

${ }^{21}$ E.g. Homer at Paul. Dig. 18.1.1.1, Ulp. Dig. 48.5.14.1; Demosthenes at Marcianus Dig. 1.3.2. See also A. Manni, 'Gli exempla greci in D. 48.19.16', in Modelli di un multiculturalismo giuridico (n. 5, above) 21964.

${ }^{22}$ E.g. Dig. 14.2.9 (Antoninus Pius), 49.1.25 (Severus Alexander) 50.6.6.2 (Pertinax).

${ }^{23}$ The fragments are most easily seen together in O. Lenel, Palingenesia Iuris Civilis, 2 vols (Leipzig 1889) I, cols 707-18. On Modestinus, at once jurist and palatine official, see F. G. B. Millar, 'The Greek East and Roman Law: The Dossier of M. Cn. Licinius Rufinus', JRS 89 (1999) 90-108 (102-03, 108) [repr. in Government, Society, and Culture in the Roman Empire (Chapel Hill - London 2004) 455-57, 463-64] and D. Liebs, Hofjuristen der römischen Kaiser bis Justinian (Munich 2010) 73.

${ }^{24}$ Dig. 27.1.1.1 (trans. The Digest of Justinian, ed. A. Watson (Philadephia 1985)).

${ }^{25} \mathrm{~V}$. Marotta, 'Eclissi del pensiero giuridico e letteratura giurisprudenziale nella seconda metà del III secolo d.C.', Studi storici 48 (2007) 927-64; L. de Blois, 'Why did the influence of scholarly jurists at the
} 
And so to the Code. Here the situation is a little different. The three pre-existing Codes used as sources had contained relatively little Greek. The Gregorian and Hermogenian Codes do not survive, but only a handful of Justinian texts in Greek can reasonably be attributed to them. ${ }^{26} \mathrm{We}$ can be more certain for the Theodosianus. There are two extracts from acta reporting speech in Greek (CTh 8.15.1, 11.39.5). Otherwise the only clear and substantial text is the law on asylum in church from 431, preserved in a single manuscript (Vat. Reg. Lat. 886), given in an edited Latin version, followed by its parallel in Greek (CTh 9.45.4-5). ${ }^{27}$ The Greek version alone is attested as present in the first book of the Justinian Code (CJ 1.12.3). ${ }^{28}$ The Latin has disappeared entirely in the Justinian tradition. However, title and constitution are missing from the register of constitutions from the first Justinian edition preserved in POxy. XV 1814 and so had probably been placed at the end of book 9 (mirroring the Theodosianus). This leaves open the possibility that the Latin was only dropped from the second edition of the Code in 534, rather than already from the first of 529, and that this reflects a different attitude towards Greek even between 529 and $534 .{ }^{29}$ Either way, however, this was the principal Greek contribution of the Theodosianus to the Justinianus.

Of the more recent material taken into the Code, Greek starts to appear more often in the second half of the fifth century, especially for the reign of Zeno onwards. ${ }^{30}$ This is not a promiscuous feature, however, for all topics of legislation equally, but occurs most often for matters relating to religion and church, regarding which the emperor had sometimes engaged with ecclesiastics in Greek, as the typical language of elite Christian

\footnotetext{
Roman imperial court disappear after AD 241', in Das Recht der 'Soldatenkaiser, eds U. Babusiaux and A. Kolb (Berlin 2015) 225-37.

${ }^{26}$ CJ 4.24.1, 10.48.2 and probably 1.9.2, 4.20.1, 9.6.1.

${ }^{27}$ B. H. Stolte, 'The use of Greek in the Theodosian Code', Subseciva Groningana 8 (2009) 147-59, noting also that the Latin of $C T h 15.1 .9$ appears only in Greek at $C J 11.8 .3$. CJ 9.36.1, probably of Julian (Avranches Bibl. Mun. MS $141 f .186^{\mathrm{r}}$ ), should have come from the Theodosianus (Corcoran, 'The Codex of Justinian' (n. 10, above) cviii n. 51 and cxli n. 210). See also J. H. A. Lokin, 'Alcune note sul bilinguismo nella legislazione romana', in Modelli di un multiculturalismo giuridico (n. 5, above) 541-67 (547-59).

${ }^{28}$ The Latin version is nowhere attested in the direct manuscript transmission, while the presence of the Greek alone is confirmed by Collectio Tripartita 1.3.parat.31 and 1.4.parat.9 (N. van der Wal and B. H. Stolte, Collectio Tripartita: Justinian on Religious and Ecclesiastical Affairs (Groningen 1994) 52, 69). Note that there is an independent transmission of the Greek text associated with the First Council of Ephesus (E. Schwartz, Acta Conciliorum Oecumenicorum 1.1.4 (Berlin 1928) 61-65 [Collectio Vaticana 137]; Millar, Greek Roman Empire (n. 4, above) 143-45).

${ }^{29}$ S. Corcoran, 'Justinian and his two codes' (n. 12, above) 94-95.

${ }^{30}$ E.g. CJ 1.2.15, 1.3.35, 8.10.12.
} 
communication, discussion, and dispute in the East. By contrast, laws which deal with the classic areas of the Roman civil law generally remain in Latin. When Tribonian comes in 530 to engage with the classical jurists and their differences of opinion, and to settle these in the Fifty Decisions, this is carried out in Latin. There are signs of change, however. For instance, in 531 a law was issued regulating the succession to freedmen. Later in the Institutes, Justinian described this as follows: 'In our constitution, however, which we have drawn up in a convenient form and in the Greek language, so as to be known by all, we have established the following rules for application to such cases' (Inst. 3.7.3). This Greek law was included in the Code (CJ 6.4.4), and seems never to have been promulgated in a formal Latin equivalent.

Greek constitutions, therefore, are scattered throughout the Code. Nonetheless, there is a heavy concentration in the first thirteen titles of book 1 , those concerned with religious issues. ${ }^{31}$ Indeed, this feature became more pronounced in the second edition of the Code. Book 1 swelled greatly, bloated with recent long constitutions in Latin or Greek. The most significant Latin texts were the two constitutions relating to the creation and promulgation of the Digest (CJ 1.17.1-2: Dig. C. Deo Auctore and Tanta). The Greek version of the promulgation constitution (Dig. C. $\Delta \varepsilon \dot{\varepsilon} \delta \kappa \varepsilon v)$ is attested solely in the sixth-century Florentinus manuscript of the Digest and is not reflected in any part of the Code tradition. ${ }^{32}$ There were also the two long constitutions organizing the civil and military administration of newly reconquered Africa (CJ 1.27.1-2). ${ }^{33}$ In the earlier religious titles of the book, however, especially in titles one, four, and five, on doctrinal belief, episcopal authority, and heretics, wordy new constitutions in Greek were added. Such may not have increased the overall proportion of Greek in the Code, being matched by the long Latin additions, including an exchange between Pope John II and Justinian on the latter's declaration of faith (Chalcedonian with a theopaschite gloss), ${ }^{34}$ but they did

\footnotetext{
${ }^{31}$ R. Forrez, 'Graeca libri primi Codicis lustiniani leguntur', in Viva vox iuris romani: Essays in Honour of Johannes Emil Spruit, ed. L. de Ligt (Amsterdam 2002) 353-59.

${ }^{32} \mathrm{~T}$. Wallinga, Tanta/ $\Delta \varepsilon \dot{\delta} \delta \omega \kappa \varepsilon v$ : Two Introductory Constitutions to Justinian's Digest (Groningen 1989).

${ }^{33}$ See now S. Corcoran, 'The Würzburg fragment of Justinian's constitutions for the administration of recovered Africa', in Libera curiositas. Mélanges d'histoire romaine et d'Antiquité tardive offerts à JeanMichel Carrié, eds S. Janniard et al. (Turnhout 2016) 97-114.

${ }^{34}$ CJ 1.1.8 (sent to the emperor from Rome in March 534), known also from Collectio Avellana 84 (cf. 91 , resubmitted by Justinian to Agapetus in 536). This seems to have been the final addition to the Code, anomalous but christologically emphatic. That it properly belongs in the Code is sometimes doubted: B. H.
} 
add considerably to the amount of legally and definitively authoritative material in Greek. Indeed, given that the new codification as a whole replaced all previously valid legislation and legal writing, there was probably more Greek embedded directly in imperial law than ever before. Nonetheless, up to 534, most legislation was issued in Latin, and the authoritative works issued in 533 and 534, although they were truly bilingual, were still predominantly Latin.

How was this corpus to be taught and used in practice, especially in the major portion of the Empire, where Greek was the default language of high culture and written communication? Justinian had taken some thought for this also. Concomitant with the publication of the Institutes and Digest in 533, there was issued a law reforming legal education (Digest C. Omnem), preserved solely in the Florentinus manuscript. According to this, teaching was now to be confined to the law schools of the 'royal' cities (Constantinople and theoretically Rome $)^{35}$ plus Beirut, with other places of instruction such as Caesarea and Alexandria no longer formally recognized. The existing teaching syllabus was also revised and expanded to accommodate Justinian's new materials, and it combined taught elements and self-study. In fact, the constitution usefully gives a full comparison of the old and new systems, but it is not actually stated what language had been or was to be used for teaching, although the issue to the law professors of a now lost Greek constitution in addition to Omnem (Dig. C. Tanta 22 and C. $\Delta \varepsilon \dot{\varepsilon} \delta \omega \kappa \varepsilon v 22$ ) suggests the pedagogical importance of Greek. ${ }^{36}$

So what had existed before? Our best snapshot of the student experience at law school is from Zacharias of Mytilene's Life of Severus of Antioch. ${ }^{37}$ According to Zacharias, Severus was educated in both Greek and Latin and, after studying rhetoric and

Stolte, 'Not in the Code, nor in the Basilica: C. 1.1.8 and its translation in the Basilica', Annali del seminario giuridico (AUPA) 54 (2010-11) 291-300.

${ }^{35}$ It is not clear that Justinian will have known what the actual situation was in Rome, although King Athalaric had attempted that same year to revivify higher education there, including law (Cassiod. Variae 9.21). See S. Corcoran, 'Roman law in Ravenna', in Ravenna: Its Role in Earlier Medieval Change and Exchange, eds J. Herrin and J. Nelson (London 2016) 163-97 (176).

${ }^{36}$ For this mysterious constitution, see Lokin, 'Alcune note' (n. 27, above) 562-66. Note that the version of Tanta at CJ 1.17.2.22 does not include reference to the Greek constitution. For the syllabus, see the table in H. J. Scheltema, L'enseignement de droit des antécesseurs (Leiden 1970) 8 [repr. in Opera Minora ad iuris historiam pertinentia (Groningen 2004) 58-110 (65)].

${ }^{37}$ For an English translation of the Syriac (the Greek original is lost), see S. Brock and B. Fitzgerald, Two Early Lives of Severos, Patriarch of Antioch (Liverpool 2013) 33-100. The Life was written at the time of Severus's appointment as bishop of Antioch in 512. 
philosophy in Alexandria at the same time as Zacharias, he moved on to law school at Beirut in the late 480s, where the two met again, with the ardent Christian Zacharias turning the pagan Severus towards Christianity. ${ }^{38}$ The routine that they came to adopt is described by Zacharias to Severus thus:

From what I've learnt, we study law the whole week apart from Sunday and Saturday afternoon. We go to the law lectures provided for us by our teachers on these other days, and afterwards we work over them again by ourselves. Then we have a rest for half a day on Saturday, prior to the Sunday, which the civil law, too, instructs that we consecrate to God. If, then, it is pleasing to you, we will set this time aside for the Doctors of the Church and their writings (Life ch. 67).

Severus is also described as intensively studying the imperial constitutions:

Severus studied the law to the utmost, and all the imperial edicts right up to his own times he examined in detail, comparing them with brief commentaries, and noting down excerpts in books, aides memoires for the forgetful, leaving for those who came after him annotations and comments, like memoranda. (Life ch. 126).

This must have included constitutions from the codes, since it was presumably from the Theodosian Code that he knew the legislation on Sunday observance. ${ }^{39}$ He is clearly meant to be a model student. What language was used in lectures, or by Severus himself in his commentaries, however, is not specified.

Of the pre-codification teaching materials themselves only a small amount survives to allow comparison in form and language. Beirut had become an important centre for the teaching of law in the third century and knowledge of Latin was associated with learning the law there. ${ }^{40}$ Libanius, always jealous of anything that might draw away

\footnotetext{
${ }^{38}$ Zacharias also refers to his own study at Beirut briefly in Ammonius 11. 6-13 (J. Dillon, S. Gertz, and D. Russell, Aeneas of Gaza, Theophrastus with Zacharias of Mytilene, Ammonius [London 2012] 101).

${ }^{39}$ See the incomplete title CTh 2.8 (plus CJ 3.12.2), with some laws under titles CTh 8.8 and 11.7.

${ }^{40}$ Most famously attested by Gregory Thaumaturgus in his Ad Origenem 5.57-62 (Millar, 'The Greek East and Roman Law' (n. 23, above) 105-08; L. Jones Hall, Roman Berytus. Beirut in Late Antiquity (London -
} 
his students, typically lamented such an abandonment of the advanced study of Greek rhetoric for law written in Latin. ${ }^{41}$ However, while some knowledge of Latin was a prerequisite for studying Roman legal texts, it is not clear that teaching itself was necessarily in Latin (and the case of Severus provides no confirmation either way). The later fifth-century law professors, the so-called 'heroes', are occasionally cited in Byzantine Greek sources, apparently in the language they lectured in. ${ }^{42}$ However, this does not preclude them from doing so in Latin also. However, practice may have varied between, say, Constantinople, as the imperial capital, and Beirut; or between Beirut and other places where teaching took place, such as Caesarea or Alexandria. There is a strong trend in modern scholarship to suppose that teaching was likely to have been in Greek even in the third and fourth centuries and that knowledge of Latin could often have been superficial (without precluding the existence of some capable bilinguals). ${ }^{43}$

The only Latin texts associated with the teaching or study of law are of western provenance. The clearest example is the Consultatio veteris cuiusdam iurisconsulti ('Consultation of some classical jurist'; later fifth-century Gaul, but only known from Renaissance printed editions), which shows use of the 'question and answer' format. ${ }^{44}$ The numerous scholia to Vat. Reg. Lat. 886, a copy of the Theodosian Code almost certainly used in early to mid-sixth-century Italy before migrating to Gaul by the early eighth century, do not seem to represent legal teaching, and in any case were mostly not written for the manuscript, but copied from a separate divergent text, and might even be

New York 2004) 203-04). For general accounts of Beirut as a law school, see P. Collinet, Histoire de l'école de droit de Beyrouth (Paris 1925); Hall, Roman Berytus, ch. 9.

${ }^{41}$ R. Cribiore, The School of Libanius in Late Antique Antioch (Princeton 2007) 205-13, suggesting that Libanius did not despise skilled Latinists as such; contra H.-G. Nesselrath, 'Libanius and the literary tradition', in Libanius: A Critical Introduction, ed. L. van Hoof (Cambridge 2014) 241-67 (251).

${ }^{42}$ E.g. Domninus, Demosthenes, and Eudoxius, the 'panaristoi' of the Civil Law: Basilica Scholia 8.2(V).79.1; Patricius and Eudoxius both 'Heroes': Basilica Scholia 11.2(CA).20.4, 11.2(CA).35.4; Eudoxius 'Hero': Basilica Scholia 11.2(CA).25. 4, 21.3.4.2, 22.1.43.2, 47.1.72.1; Cyrillus 'Hero': Basilica

| Scholia 18.5.9.17 (mentioning Beirut specifically). See also PLRE II Cyrillus 2, Demosthenes 2, Domninus 5, Eudoxius 4, Patricius 10. Note the collection of texts based mostly on older Basilica editions in E. Seckel and B. Kübler, Iurisprudentia Anteiustiniana II.2 (Leipzig, 1927) 515-43.

${ }^{43}$ Thus Cribiore in School of Libanius (n. 41, above), generally following B. Rochette, Le latin dans le monde grec (Brussels 1997) 170-74. Both report the view of one of the few Romanists to doubt early teaching in Latin, F. Schulz, Roman Legal Science (Oxford 1946) 276.

${ }^{44}$ Edition in P. Krüger, Collectio librorum iuris anteiustiniani III (Berlin 1890) 201-20. Matthijs Wibier (of REDHIS: see below, n. 47) is working on a new edition and analysis of this text. 
of eastern origin. ${ }^{45}$ This leaves open the question of how far the copyists or users of this manuscript may have been primarily Greek or Latin speakers. ${ }^{46}$

What do pre-Justinian materials from the East reveal $?^{47}$ Although there seems to be a wide range of types, most texts are highly fragmentary and it is not easy to be sure which were intended for teaching as opposed to practice. While some texts are solely in Greek, many manuscripts are digraphic, written in both Greek and Latin language and script, and usually with the correct script for the language, if with some contamination (given that many Greek and Latin letters are identical or similar, especially in uncial scripts). ${ }^{48}$ Comment or gloss is in Greek, but the source legal texts themselves and many technical terms are kept in Latin.

One of the more extensive surviving examples is the Scholia Sinaitica. ${ }^{49}$ This work represents a lemmatized commentary on Ulpian's commentary on Sabinus's commentary on the Civil Law (a nice reflection of the layered 'onion nature' of Roman legal writing). This was perhaps a teaching tool, maybe even a foreshadowing by some Beirut 'hero' of how sixth-century teaching was to develop. ${ }^{50}$ Since this cites the Theodosian Code, it is dated to the period between Theodosius and Justinian. The discussion is in Greek. Technical terms and names are given in Latin, but with Hellenized endings naturalizing them in the surrounding text. All the lemmata from Ulpian, on which comment is made, are given in Latin. This is truly bilingual engagement. It is not clear if the commentary has been extracted from an annotated manuscript of the original work, or was written to be self-standing from the start. However, either way the commentary only makes sense for someone who had at least occasional access to the full text of Ulpian.

\footnotetext{
${ }^{45}$ For a long discussion of the fiendish complexities and theories about the manuscript and its scholia, see J. M. Coma Fort, Codex Theodosianus. Historia de un texto (Madrid 2014) 67-90.

${ }^{46}$ For instance, a Greek speaker seems to have marked up the Latin with word divisions (E. Dickey, 'Word division in bilingual texts', in Signes dans les textes, textes sur les signes, eds G. Nocchi Macedo and M. C. Scappaticcio (Liège 2017) 159-75 [172-73]).

${ }^{47}$ The REDHIS project at Pavia ('Rediscovering the hidden structure: A new appreciation of juristic texts and patterns of thought in late antiquity'; http://redhis.unipv.it/), run by Dario Mantovani, promises important new editions and a revolution in our understanding of late-antique juristic literature before Justinian.

${ }^{48}$ On the digraphic phenomenon, see in general Bilinguisme et digraphisme dans le monde gréco-romain, eds M.-H. Marganne and B. Rochette (Liège 2013).

${ }^{49}$ Krüger, Collectio (n. 44, above) 269-82; also Krüger, 'Die Sinai-Scholien zu Ulpians ad Sabinum', ZRG 4 (1883) 1-32 (with apograph). A fresh edition by REDHIS is planned.

${ }^{50} \mathrm{~K}$. McNamee, 'Another chapter in the history of scholia', $C Q 48$ (1998) 269-88.
} 
For the Gregorian Code, we have little evidence. Later references certainly mention or imply use of this by the fifth-century teachers. ${ }^{51}$ However, there are two more recent pieces of evidence. First is the Fragmenta Londiniensia Anteiustiniana, seventeen small parchment fragments identified in 2010 by Benet Salway and myself as most likely coming from a copy of the Gregorian Code. ${ }^{52}$ Written in a small but very clear and consistent uncial, the text, such as it survives, is entirely Latin. However, the original manuscript was surely written in the East. First, traces of Syriac show that the parchment was reused some time after 1000 in the Near East. Second, there are Greek glosses, hard to read, but placed above specific words. One of the clearest examples is the glossing of

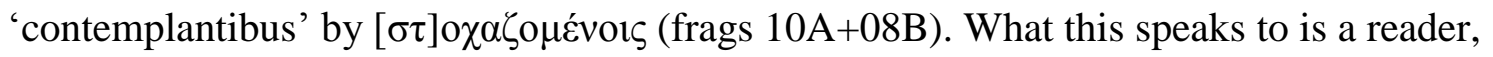
one generally fluent in Latin, but needing occasional help or reminders for particularly rare words or unusual constructions.

The second piece of evidence is a fragmentary papyrus from Berlin (PBerol. Inv. 16977), ${ }^{53}$ as boldly reinterpreted in an as yet unpublished re-edition. ${ }^{54}$ This comprises what appears to be a Greek summary or commentary to a series of constitutions from one title of the Gregorian Code. ${ }^{55}$ Each constitution is identified by an abbreviation of the emperor's name and the first two words in Latin (e.g. "Ant. Cum fidem"; $c f . C J$ 4.30.4). Like the Scholia Sinaitica, this appears to presume access to the source text.

A final piece of evidence relates to the Theodosian Code. Franz Mitthof has identified a small piece of papyrus as containing fragments of Greek, which relate apparently to a sequence of constitutions from book 9 of the Theodosian Code.$^{56}$ The rubrics seem to have been included in Latin, but it is possible that this was a summary of

\footnotetext{
${ }^{51}$ See n. 42, above. Explicit mentions of the pre-Justinian codes in the Basilica scholia are rare (Bas. Schol. 11.2(CA).35.3; 11.2(P).60.2).

${ }^{52}$ S. Corcoran and B. Salway, 'Fragmenta Londiniensia Anteiustiniana: preliminary observations', Roman Legal Tradition 8 (2012) 63-83.

${ }^{53}$ Earlier accounts of the papyrus can be found in W. Schubart, 'Actio condicticia und longi temporis praescriptio', in Festschrift für Leopold Wenger zu seinem 70. Geburtstag, II (Munich 1945) 184-90 and E. Schönbauer, 'Ein wichtiger Beispiel der nachklassischen Rechtsliteratur', in Studi in onore di Vincenzo Arangio-Ruiz nel XLV anno del suo insegnamento, III (Naples 1953) 501-19.

${ }^{54}$ I am grateful to Lothar Thüngen for sharing with me his draft article 'Zwei Fragmente frühbyzantinischer Rechtsliteratur aus Hermupolis Magna. Neu-Edition von P. Berol. inv. 16976 und 16977’, $Z R G$ (forthcoming). The REDHIS project is also planning an edition of the papyrus.

${ }^{55}$ Identified by Thüngen as $C G$ 4.8: De non numerata pecunia.

${ }^{56}$ F. Mitthof, 'Neue Evidenz zur Verbreitung juristischer Fachliteratur im spätantiken Ägypten', in Symposion 2003, ed. H.-A. Rupprecht (Vienna 2006) 415-22; cf. the list of constitutions in P. Ryl. III 476 (K. McNamee, Annotations in Greek and Latin texts from Egypt (Oakville, CN 2007) 505-06 [no. 2282]).
} 
some or all of the Code in Greek, that could have served as a shortcut for someone daunted by the main text. Whether it was produced in a didactic context is unknown. What is notable, however, is that whatever works were being created to assist the study or use of the Roman legal texts, which themselves were preserved in Latin, in the East these preferred to use Greek not Latin for explanation and interpretation.

Whatever had gone before, Justinian himself now issued instructions on what could be written about or on his new legal materials. ${ }^{57}$ There has been considerable scholarly debate over Justinian's supposed ban on commentaries, in which I do not want to drown here. ${ }^{58}$ It is possible it was meant to apply to the Digest alone. Nor was it necessarily intended to curtail didactic materials. Certainly Justinian drew a parallel with the lengthy and disputatious juristic commentaries on the Praetor's Edict, so that, wishing to keep his reformed law clear and consistent, he sought to prevent sixth-century legal scholars from arguing such varying interpretations in long treatises that they thereby confounded his hard-won legal harmony. However, Justinian does explain what types of writing he will allow, and this helps to illuminate the sorts of texts that were being created, specifically those which were added to the texts of the codification. In

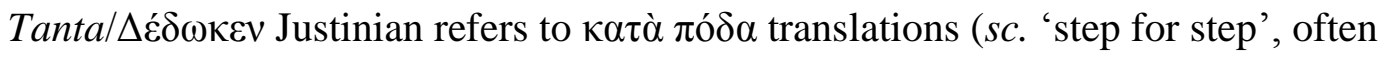
rendered in the plural as $\kappa \alpha \tau \grave{\alpha} \pi$ ó $\delta \alpha \varsigma)$, which followed the source text word for word without deviation. He also refers to $\pi \alpha \rho \alpha ́ \tau ı \tau \lambda \alpha$ (in both Deo Auctore and Tanta), brief explanatory summaries added in the margins, that served as a guide to content. ${ }^{59}$ The point of these types of material was that they were not intended to give the jurists a chance to argue alternative, let alone imaginatively new, views. Rather, they were supposed to explain what was there already, to make its meaning clearer, and to help navigate the new codification.

Certainly, it seems that almost immediately a sizeable body of teaching materials for the codification came into being and rapidly expanded, mostly being produced within a decade of the codification. Because these and related materials in Greek ultimately

\footnotetext{
${ }^{57}$ Dig. C. Deo Auctore 12 (= CJ 1.17.1.12) [530], C. Tanta 21 (= CJ 1.17.2.21) and C. $\Delta \varepsilon ́ \delta \omega \kappa \varepsilon v 21$ [533].

58 The literature on this topic is vast. For recent discussions, see G. Falcone, 'The prohibition of commentaries to the Digest and the antecessorial literature', Subseciva Groningana 9 (2014) 1-36 and T. Wallinga, 'The reception of Justinian's prohibition on commentaries', $R I D A^{3} 59$ (2012) 375-86.

${ }^{59}$ Falcone, 'The prohibition' (n. 58, above) 11-13. Falcone notes that the term 'index' used in Deo Auctore seems to be synonymous with paratitla, and that Justinian does not repeat it in Tanta, to avoid confusion with the long lecture course indices discussed below. The terminology is trickily protean.
} 
replaced Justinian's original corpus in one form or another in the Empire, we have a considerable range of surviving texts to study.

How, therefore, do you teach the law syllabus in the sixth century? The key modern scholar, here, is Scheltema, particularly in his short 1970 book on the legal teaching of the antecessores, the law professors. ${ }^{60}$ Through a detailed study of the surviving fragments and the indications they gave of the original nature of their materials, Scheltema came up with the following schema for how teaching was done. Each work was covered by a twofold course. First a series of lectures would present a summary of the texts in Greek (that is, where teaching was in Greek), a summary usually referred to as an index. This might be a simple translation or paraphrase of the Latin, but usually tended to be more prolix. A particular feature is the use of $\pi \rho 0 \theta \varepsilon \omega \rho i \alpha$ ('protheories'), introductory passages, setting out what had previously been discussed and giving background context. Those of Stephanus on the Digest tend to be extremely lengthy, ${ }^{61}$ usually fortified by $\theta \varepsilon \mu \alpha \tau 1 \sigma \mu o i ́$ or examples, often using those juristic stalwarts Maebios and Titios, or Primos and Sekondos. ${ }^{62}$ Whatever the nature of the exposition, it would then lead on to the main point of the passage, which would be a version of Justinian's text. The index therefore is effectively a lecture course that aims to give the student all the essential knowledge about the content of the source works and the crucial issues at stake, sometimes at considerably greater length than the work being commented on. The students could thus acquire a good knowledge of the legal content without even needing to read the originals.

However, the students may well at this stage have had before them copies of the source text, or at least the relevant part, denoted by the term $\tau$ o $\rho \eta \tau$ óv. It seems unlikely to me that the teacher dictated the Latin original in addition to the Greek version, since the audience would surely have found Latin extremely difficult to follow and this would hardly favour faithful renderings of an authoritative text, the format of which the emperor was so concerned with controlling. It seems more likely that students came to class with a

\footnotetext{
${ }^{60}$ Scheltema, L'enseignement (n. 36, above); $c f$. also his 'Byzantine law', in The Cambridge Medieval History IV.2, eds J. R. Tanner et al. (Cambridge 1967) 55-77 (56-60) [repr. Opera Minora (n. 36, above) 39-42].

${ }^{61}$ On Stephanus, see Scheltema, L'enseignement (n. 36, above) 24-29.

${ }^{62} C f$. these names in Theophilus (Theophili antecessoris Paraphrasis Institutionum, eds J. H. A. Lokin et al. (Groningen 2010) xxiii).
} 
section of text, perhaps having bought or borrowed these in short fascicles so as to spread out the expense and effort of buying or copying so large a corpus all at once, as was the

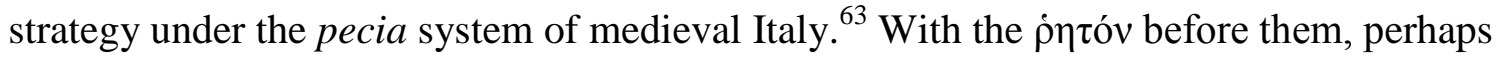
this was the point where kata poda or other versions were created, the students trying to copy down the Greek (which they understood very well) against their existing copy of the Latin. $^{64}$

It is easy to imagine this being done for the Code, whose Latin was especially difficult, taught in the fifth and final year of the law course. Consider this example from Thalelaeus, author of much of the surviving antecessorial literature on the Code. ${ }^{65}$ First he sets out the presumed background for which the rescript was being issued, followed by a Greek kata poda translation (bold, not quite word for word), ${ }^{66}$ which I have set above the Latin rescript (CJ 2.51.1; italics). This suggests that the original text may already have been in front of the students, onto which they scribbled their version of the crib. The emperor (Alexander) is unidentified, but would have been apparent to anyone using the source text and is in any case legally irrelevant:

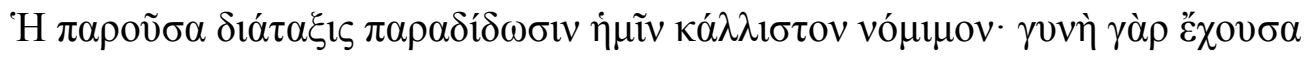

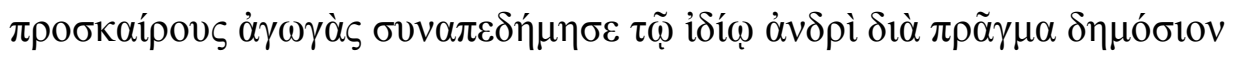

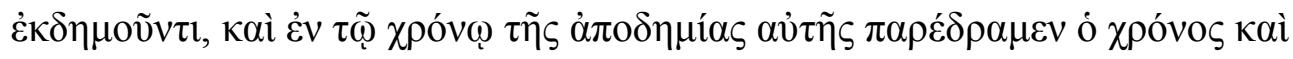

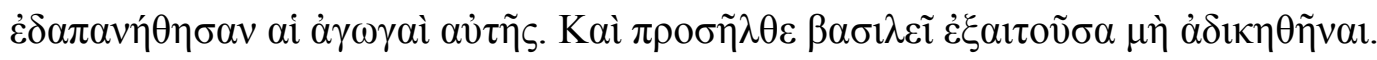

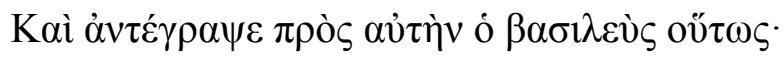

\begin{tabular}{|c|c|c|c|c|c|}
\hline$\tau \tilde{\omega} v \pi \rho 0 \sigma \kappa \alpha i ́ \rho \omega v$ & $\dot{\alpha} \gamma \omega \gamma \tilde{\omega} v$ & 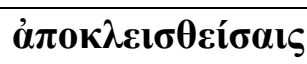 & 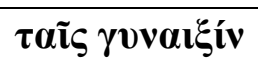 & dî́tıves & $\mu \varepsilon \tau \grave{\alpha}$ \\
\hline temporalibus & actionibus & exclusis & mulieribus & quae & cum \\
\hline
\end{tabular}

\footnotetext{
63 J. A. Brundage, The Medieval Origins of the Legal Profession (Chicago 2008) 272-73.

${ }^{64}$ This would surely necessitate clear word division to match up the texts. See Dickey, 'Word division' (n. 46, above).

${ }^{65}$ For Scheltema's view of Thalelaeus and the kata poda, see Scheltema, L'enseignement (n. 36, above) 32-40; $c f$. notes 80-81 below.

${ }^{66}$ To match the Greek more closely, the Latin would have to have read subvenire nos, but, as noted below, kata poda may reflect idiomatic practice and are not necessarily mechanically exact in either creation or transmission.
} 


\begin{tabular}{|c|c|c|c|c|}
\hline$\tau \tilde{\omega} v \dot{\alpha} v \delta \rho \tilde{\omega} v \tau \tilde{\omega} v$ & $\delta ı \grave{\alpha} \pi \rho \tilde{\alpha} \gamma \mu \alpha \delta \eta \mu o ́ \sigma t o v$ & $\dot{\alpha} \pi \hat{v} v \tau \omega v$ & 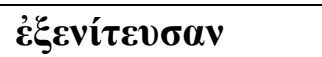 & 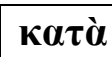 \\
\hline maritis & reipublicae causa & absentibus & peregrinatae sunt & $a d$ \\
\hline
\end{tabular}

\begin{tabular}{|c|c|c|c|c|c|c|c|}
\hline$\mu \mathbf{I}^{\prime \mu \eta \sigma \iota v}$ & $\tau \tilde{\omega} v \sigma \tau \rho \alpha \tau \iota \omega \tau \tilde{\omega} v$ & $\sigma v v \tau \rho \varepsilon ́ \chi \varepsilon เ v$ & $\dot{\eta} \mu \tilde{\alpha} \varsigma$ & 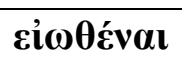 & оข่к & 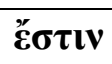 & ä $\gamma v \omega \sigma \tau 0 v$. \\
\hline exemplum & militum & subveniri & & solere & non & est & ignotum. \\
\hline
\end{tabular}

The present law provides us with a very fine ruling. Now a woman with timelimited actions was away with her husband, who was abroad on account of public business, and during the time of her absence the time ran out and her actions were exhausted. And she approached the emperor asking that she not suffer injustice. And the emperor wrote back to her thus: It is not unknown, on the analogy of soldiers, that we have been accustomed to accommodate women barred by time-limited actions, who went abroad with husbands absent because of public business (Basilica 10.35.47).

Anyway, once the students had had their Greek overview, and became furnished with copies of the source text, the second part of the course could proceed, being made up of the $\pi \alpha \rho \alpha \gamma \rho \alpha \varphi \alpha i$, detailed comments or annotations on particular passages, designed precisely to enable the student to engage in more detail with the Latin source text itself, which the student now had the tools to understand. Thus the teacher could refer the student to the actual words of the original on which he is commenting (e.g. P. Reinach $2173=$ Stephanus on Dig. 19.2.54). ${ }^{67}$ The word paragraphai is used to describe the written versions of these comments that would be added in the margins of the source text, as was common for annotations on any genre of text. ${ }^{68}$ Indeed, the Scholia Sinaitica are essentially a set of paragraphai making up a continuous commentary.

Other teaching tools to note include:

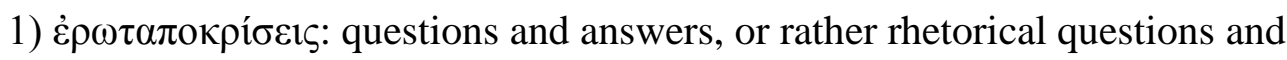
answers. It is not clear whether teachers took live questions from the students, or

\footnotetext{
${ }^{67}$ Scheltema, L'enseignement (n. 36, above) 66-67; McNamee, Annotations (n. 56, above) 499-500, no. 2971.

${ }^{68}$ McNamee, Annotations (n. 56, above) 19.
} 
otherwise based these on past student queries, or if they were purely rhetorical questions devised by the teacher, although Scheltema argues that some at least reflect the real-life classroom. ${ }^{69}$ As noted above, this feature is found in the Consultatio, whose very name suggests it. This format is found in other genres and disciplines as well. ${ }^{70}$

2) the highlighting of particularly important or fine passages, marked by terms

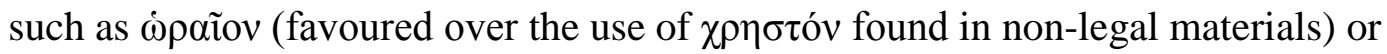
$\sigma \eta \mu \varepsilon i ́ \omega \sigma \alpha l$ (Nota, in the Latin West), which again is a fairly universal practice across most genres of text. ${ }^{71}$

3) the provision of cross-references to other relevant texts, for which the term is $\pi \alpha \rho \alpha \pi \circ \mu \pi \alpha i$. These were a key feature of paragraphai or paratitla (the latter of which often contain little more than parapompai), and made the navigation of the large works more practicable. Their extensive survival as numerical references in the Byzantine sources has made easier the reconstruction of the more poorly transmitted parts of the Justinianic corpus (and indeed the Basilica).

It must be stressed here that Scheltema's two-part teaching structure is inference from the range of available materials. In fact only one law school work in Greek survives intact, the paraphrasis of the Institutes by Theophilus (also co-author of Justinian's original) ${ }^{72}$ which cannot easily be divided into the two-part course and, although it does contain the broad range of approaches outlined above that are features of antecessorial teaching, scholars do not agree in their interpretations of its shape. ${ }^{73}$ In any case, since the surviving text only begins at book 1 title 2, lacking any original preface, we do not know whether this work was published by him, or put together by students or fellow antecessores after his death, presumed to have occurred before the end of $534 .^{74}$ Given how quickly the new materials were created in the 530s, it makes sense to suppose that existing materials were recycled and adapted. For instance, Theophilus's account of

\footnotetext{
${ }^{69}$ Scheltema, L'enseignement (n. 36, above) 10.

${ }^{70}$ Erotapokriseis: Early Christian Question-and-Answer Literature in Context, eds A. Volgers and C. Zamagni (Leuven 2004) and La littérature des questions et réponses dans l'Antiquité profane et chrétienne: de l'enseignement à l'exégèse, ed. M.-P. Bussières (Turnhout 2013).

${ }^{71}$ McNamee, Annotations (n. 56, above) 123.

${ }^{72}$ Theophili antecessoris Paraphrasis Institutionum, eds J. H. A. Lokin et al. (Groningen 2010).

${ }^{73}$ Lokin, Paraphrasis (n. 72, above) ix-xviii, comparing the views of Scheltema and Falcone.

${ }^{74}$ For a recent discussion favouring this as a direct Theophilan creation, see C. Russo Ruggeri, 'Theophilus and the student publisher: a resolved issue?', Subseciva Groningana 9 (2014) 99-120.
} 
freedmen in book 1 of the Institutes (Paraphr. 1.5.3), discusses Junian Latins at some length in a way that was not exactly necessary, given the abolition of the status $(C J$ 7.6.1). Although he might have included a historical excursus in a freshly prepared text, we might rather presume that, having already spent years lecturing on Gaius's Institutes, he then adapted such lectures to the abolition of the status in 531, and then adapted them again once Justinian's new Institutes superseded Gaius late in 533. As suggested for the kata poda below, translations or interpretations that appear inconsistent with the transmitted Justinianic texts may suggest a survival, perhaps by inadvertence, from earlier teaching materials that had been recycled at speed.

Finally, more must be said of the kata poda translation, already mentioned. We have been presuming a system of teaching in Greek, because of our reliance upon later Byzantine sources preserving this material, but all the other forms of text discussed above could exist just as well in Latin as in Greek. However useful they might be for accessing texts in a language that was not one's preferred language, they were useful beyond the needs of crossing the language barrier. The kata poda, however, was different, and as we have seen, was a tool for a Greek-speaking student to cope with a Latin text. A kata poda text is a literal word for word version of a text rendered into another language, supposedly written between the lines of the text translated, each word above the word it translates or glosses, necessitating also clear word division. Interlinear Greek glosses of individual words, of course, are found in earlier Latin texts from the East, both the nonlegal and the legal (as with the Fragmenta Londiniensia). ${ }^{75}$ In theory, if more and more words were marked up, one could eventually mark up the entire text. Given that Greek and Latin are both highly inflected languages, this could create a version that would make some sort of sense, if read continuously, even if being far from idiomatic, let alone elegant. It is not clear that this gradual process is what happened.

The best-known kata poda texts are the colloquia used for elementary language teaching, probably originally for Latin speakers learning Greek, but which ended up used in both directions (and for Coptic as well). These are carefully designed as an elementary teaching tool. Most of these have recently been edited by Eleanor Dickey in an

\footnotetext{
${ }^{75}$ E.g. McNamee, Annotations (n. 56, above) 490-91 (POxy. XXIV 2401,Terence), 493 (PSI XI 1182, Gaius).
} 
impressive edition. ${ }^{76}$ They could also serve other purposes, such as handbooks of etiquette providing pro forma versions of letters for different social situations, even including congratulations for a new freedman on his manumission (e.g. P. Bon. 5). The legal kata poda, however, are something quite different. The elementary kata poda do include much reference to legal matters and some are even narrowly legal, perhaps suggesting an adult learner preparing for more formal training in law, ${ }^{77}$ as with the Sententiae of Hadrian and the tract on manumission. ${ }^{78}$ However, the types we are dealing with were rather a tool of higher vocational education, not elementary instruction. They were also more extensive. The amount of parallel text created ended up being very great, even if only part of it survives today. The aim of the kata poda was not to replace the source text, but to make it accessible. A good translation might rather replace the source, not supplement it. Indeed, is this what Dorotheus intended with his Digest translation (datable to the late 530s), which was not kata poda $?^{79}$ No doubt a teacher might hope that students would only continue to use the kata poda until such time as their language skills had improved to survive without it, just as a tutor in more recent times might hope that the student would cease to look at the right-hand page of the Loeb (or Budé), or even bring along instead the Oxford Classical Text or Teubner with Greek or Latin text only.

For Justinian's codification, the main kata poda to survive in part in the Byzantine tradition (mainly the Basilica) is that for the Code, which tends to be associated with Thalelaeus's materials, although it remains disputed whether it was created by him as an organic text dictated to students (as was imagined above), or was more haphazard. Indeed, it has been argued that, under pressure of time to create his lectures, the quality of the versions declines from book 3 onwards. ${ }^{80}$ Possibly some partial kata poda already existed, especially as Justinian's reference suggests they were normal already in 533.

\footnotetext{
${ }^{76}$ E. Dickey, The Colloquia of the Hermeneumata Pseudodositheana, 2 vols (Cambridge 2012-2015).

${ }^{77}$ E. Dickey, 'New legal texts from the Hermeneumata Pseudodositheana', RHD 82 (2014) 30-44.

${ }^{78}$ Texts: G. Flammini, Hermeneumata Pseudodositheana Leidensia (Leipzig 2004) 67-77 and 92-103 (earlier edition at Corpus Iuris Romani Anteiustiniani I, (eds) E. Böcking et al. (Bonn 1837) 193-227). Discussion: A. M. Honoré, 'The Fragmentum Dositheanum', RIDA 12 (1965) 301-23; A. Schiller, 'Vindication of a repudiated text: Sententiae et Epistulae Hadriani', in La Critica del Testo (Florence 1971) 717-27; B. Rochette, 'Les Hadriani sententiae: quel latin?', in Latin vulgaire, latin tardif IX, eds F. Biville et al. (Lyon 2012) 807-20; Dickey, Colloquia (n. 76, above) I, 28-30.

${ }^{79}$ F. Brandsma, Dorotheus and his Digest Translation (Groningen 1996).

${ }^{80} \mathrm{~S}$. Sciortino, 'La relazione tra il kata podas e le traduzioni di Taleleo dei rescritti latini del Codex', AUPA 56 (2013) 113-57.
} 
Because they are supposed to match their source text so exactly, it is easy to see if and how they differ. Divergences from the Latin text, especially if close to surviving source texts like the Theodosianus, have been used to suggest that kata poda may have existed for at least parts of the pre-Justinianic codes or indeed for the first edition. ${ }^{81}$ Of course, we cannot be sure when the kata poda became detached from the source text to become a self-standing work. A source text could easily have phrases or sentences to which no translation was added. A kata poda does not have to be complete, but this might not prevent it being detached, even so, with gaps silently and confusingly closed up or supplemented with bad transcriptions of the source text, and no doubt later copyists might further emend the text to make more sense. Unfortunately, there exists no interlinear kata poda manuscript of the sixth century to show how this might have looked or been laid out or how complete the text was or how word division was managed. We have glosses of individual words and marginal annotations, but nothing remotely resembling an extensive interlinear crib. ${ }^{82}$ Whoever used the Verona Code palimpsest (Verona Bibl. Cap. LXII[60]), for instance, seems to have been quite at home with bilingual legal texts, annotating extensively in Greek with notes and cross-references like an experienced practitioner or even antecessor, who needed little help with the Latin language. ${ }^{83}$

It should also be noted that the colloquia texts discussed above, of which ancient examples do survive, are not interlinear, but are laid out in narrow adjacent columns, probably in origin of Roman devising, with Latin on the left, Greek on the right, where the line breaks and parallels tend to follow sense rather than proceeding mechanically word for word, and this allows the translation to be a little more idiomatic. This applies

\footnotetext{
${ }^{81}$ On this contentious topic, see A. Berger, 'Studies in the Basilica I: to kata podas', BIDR 55/56 (1952) 65-184; N. van der Wal, Les commentaires grecs du code de Justinien (The Hague 1953); D. Simon, 'Aus dem Codexunterricht des Thalelaios: D. Divergenzen zwischen Thalelaios-Kommentar und Codex Überlieferung', RIDA 17 (1970) 273-311; D. Holwerda, Exempla Philologica (Groningen 2000) 1-15; S. Sciortino, 'Conjectures regarding Thalelaios' commentary on the Novus Codex', Subseciva Groningana 9 (2014) 157-185.

${ }^{82}$ E.g. PSI XIII 1347, McNamee, Annotations (n. 56, above) 499.

${ }^{83}$ C. E. Zachariae von Lingenthal, 'Die griechischen Scholien der rescribierten Handschrift des Domkapitels zu Verona’, Zeitschrift für geschichtliche Rechtswissenschaft 15 (1850) 90-132; H. J. Scheltema, 'Die veronensischen Kodexscholien', RHD 30 (1962) 252-53 [repr. Opera Minora (n. 36, above) 111-12]; B. H. Stolte, 'La lingua giuridica del sesto secolo: greco o latino? Un dilemma falso', in Modelli di un multiculturalismo giuridico (n. 5, above) 703-12 (705-09).
} 
also to Latin literary texts with Greek crib translations, although no juristic texts exist in this format, nor is this in evidence for the Justinianic material. ${ }^{84}$

Surviving late-antique bilingual Biblical manuscripts are also laid out in parallel short lines to enable comparison, generally with the Greek text on the verso of one folio (the position of honour), the Latin on the recto of the succeeding folio, ${ }^{85}$ although sometimes the Greek and Latin appear in parallel columns on the same page (as with the colloquia). ${ }^{86}$ However, the Latin is not created specifically as a crib for the Greek, but usually represents an existing Latin version, and, even if sometimes adapted, it can be rather divergent. Manuscripts with interlinear versions trying to match word for word are not attested until the ninth century. ${ }^{87}$ The examples closest to what we might imagine for the legal kata poda texts are those with interlinear Anglo-Saxon glosses added above the Latin, which make up almost continuous translated text, ${ }^{88}$ although the differences between the languages makes this a very imperfect kata poda, as one finds indeed with some modern Greek-English New Testament cribs. ${ }^{89}$

Thus far the codification, its promulgation and incorporation into the law school syllabus. From 535, most surviving legislation, as known principally from the Novels, is in Greek. There is little doubt that Greek was on its way to predominating and eventually monopolizing imperial law-making, and to becoming the sole language of Roman law in the Empire. Indeed, it is precisely in the sixth century that we see the Greek legal language for dealing the Roman law settling down and acquiring a relatively stable vocabulary, a mixture of translated and transliterated terms (although many Latin terms continued to be copied in Latin script even beyond the sixth century), in a process that was surely tied to the creation of the Greek teaching corpus for the newly authoritative codification in a small number of approved centres, together with the production of

\footnotetext{
${ }^{84}$ Well explained in E. Dickey, 'Columnar translation: an ancient interpretive tool that the Romans gave the Greeks', CQ 65 (2015) 807-821.

${ }^{85}$ D. C. Parker, An Introduction to New Testament Manuscripts and their Texts (Cambridge 2008) 68-70; H. A. G. Houghton, The Latin New Testament: A Guide to its Early History, Texts and Manuscripts (Oxford 2016) 27-29. Most famous, perhaps, is the Codex Bezae (Houghton, Latin New Testament, 212-13 [VL5]).

${ }^{86}$ E.g. Houghton, Latin New Testament (n. 85, above) 52 and 233 [VL50]).

${ }^{87}$ Houghton, Latin New Testament (n. 85, above) 78-80.

${ }^{88}$ Houghton, Latin New Testament (n. 85, above) 72-73, 279 [London BL Cotton Nero D.IV, c. 700 with late tenth-century gloss]; $c f$. BL Cotton Vespasian A.I (c. 720, mid-ninth-century gloss).

${ }^{89}$ E.g. The New Greek-English Interlinear New Testament, ed. J. D. Douglas (Carol Stream IL 1990).
} 
bilingual legal glossaries. ${ }^{90}$ Emblematic of this process is the fact that, at this time, John the Cappadocian decided that all administration in the eastern prefecture (the largest and most important part of the Empire), even up to the highest levels, should be in Greek. ${ }^{91}$ In this context, that even general laws for the East should now also be in Greek makes sense. Laws issued to Latin-speaking areas continued to be in Latin, namely Illyricum, Africa, or, later, Italy. Further, important laws on imperial constitutional matters were also kept suitably in the imperial language. Thus Novel 62 (537), the law on senatorial status and functions, with its magniloquent proem describing Roman constitutional history, was issued in Latin to none other than John the Cappadocian. It is perhaps also notable that, of the two Justinianic Novels known in contemporary copies from Egypt, this one has been identified there in a Latin fragment (PSI XIII 1346), ${ }^{92}$ while Edict XIII on the administration of Egypt is known only in Greek (POxy. LXIII 4400). Neither is known to have existed in the other language.

In fact, our knowledge of the Novels is rather skewed by the process of collection. Justinian may have intended that there would in due course be an official collection of his new laws ( $C J$ C. Cordi 4), especially since so many of the Novels ended up containing significant reforms. But he never managed to do so. As a result, several different collections of the Novels were built up and had come into existence by the 570s. Only one of these can be fully reconstructed today (the so-called Collection of 168 Novels), ${ }^{93}$ while the others are inferred from the derivative materials produced from them. They were all compiled or edited, however, either at Constantinople or elsewhere within the eastern prefecture. Only small sets of constitutions in Latin were ever collected

\footnotetext{
${ }^{90}$ B. H. Stolte, 'Graeca Pandectarum in Basilicis', Subseciva Groningana 9 (2014). For the Byzantine lexica and their tradition, see Fontes Minores VIII: Lexica Iuridica Byzantina, eds L. Burgmann et al. (Frankfurt 1990). Also useful are A. Avotins, On the Greek of the Code of Justinian (Hildesheim 1989) and On the Greek of the Novels of Justinian (Hildesheim 1992).

${ }^{91}$ C. Kelly, Ruling the Later Roman Empire (Cambridge, MA - London 2004) 32-36.

${ }^{92}$ S. Corcoran, 'Two tales, two cities: Antinoopolis and Nottingham', in Wolf Liebeschuetz Reflected: Essays Presented by Colleagues, Friends and Students, eds J. Drinkwater and R. W. B. Salway, (London 2007) 193-209.

${ }^{93}$ This is the principal version in Corpus Iuris Civilis III: Novellae, eds R. Schoell and W. Kroll (Berlin 1895). It was the basis for Theodore of Hermopolis's Breviarium (C. E. Zachariae von Lingenthal, Anekdota III (Leipzig 1843) 1-165). On the Novels and their tradition, see Novellae Constitutiones: l'ultima legislazione di Giustiniano tra Oriente e Occidente da Triboniano a Savigny, eds L. Loschiavo et al. (Naples 2011).
} 
independently in Africa or Italy. ${ }^{94}$ It must be stressed, here, that the eastern collections of Novels were all genuinely bilingual in their original formats, in that they contained some material in Greek, and some in Latin. But it seems to have been very rare for pronouncements to be issued simultaneously in both languages, unless sent to different areas. For instance, legislation on peasant loans was issued to the praetorian prefect of Illyricum in Latin, but in the diocese of Thrace (part of the eastern prefecture), the governor of Greek-speaking Haemimontus received it in Greek, his colleague in Latinspeaking Moesia Secunda in Latin. ${ }^{95}$ It is of course possible that such cases, and Latin legislation in general, are under-represented because of eastern collecting practices, which would pass over Latin, where Greek was available. For instance, Novel 17 is a long law reforming, indeed effectively reintroducing, the mandata for governors, the standing instructions for their conduct in office. ${ }^{96}$ It survives in Greek in the Collection of 168 Novels. However, in the Authenticum (also 17), although most of the Latin text appears to be a kata poda derived from the Greek, there is a grand historically-minded preface not paralleled in the Greek. Perhaps this was never rendered into Greek, just as with the law on senators, although it may indeed have prefaced the Greek version in the East. ${ }^{97}$ Not only does this preserve some of the original Latin, written by Tribonian to himself, but also makes explicit that the 'Book of Mandates' had been composed utraque lingua, which would thus justify truly bilingual circulation. However, from the Greek tradition, we would be almost unaware of the fuller Latin version. Nonetheless, laws were generally issued in one or other language, with laws issued in Greek to the eastern prefecture predominating. ${ }^{98}$

\footnotetext{
${ }^{94}$ W. Kaiser, Authentizität und Geltung spätantiker Kaisergesetze: Studien zu den Sacra Privilegia Concilii Vizaceni (Munich 2007); D. Liebs, Jurisprudenz im spätantiken Italien 260-640 n.Chr. (Berlin 1987) 195273 (on the contentious legal works associated with sixth-century Italy).

${ }^{95}$ Novels 32-34 (Schoell/Kroll, Corpus Iuris Civilis III (n. 93, above) 239-41); W. Kaiser, 'Die Zweisprachigkeit reichsweiter Novellen unter Justinian', ZRG 129 (2012) 392-474 (460-67). Note that the twin Digest constitutions, Tanta and $\Delta \varepsilon \delta \delta \omega \kappa \varepsilon v$, are not quite parallel texts and their relationship is rather vexed (see Wallinga, Tanta, n. 32, above).

${ }^{96}$ Schoell/Kroll, Corpus Iuris Civilis III (n. 93, above) 117; Kaiser, 'Die Zweisprachigkeit' (see n. 95, above) 434-37.

${ }^{97}$ The opening Latin words were known to Athanasius in his Novels summary (D. Simon and Sp. Troianos, Das Novellensyntagma des Athanasios von Emesa (Frankfurt 1989) 144).

${ }^{98}$ Fullest treatment of this question is in Kaiser, 'Die Zweisprachigkeit' (n. 95, above) 392-474; $c f$. Kaiser, 'Justinian and the Corpus Iuris Civilis' (n. 10, above) 140-41.
} 
Even if the Novels, as preserved, do slightly underplay the amount of legislation that was still issued in Latin, Greek advanced rapidly after 534 as the language for lawmaking. This, therefore, explains something of how the Novels came to be taught. As we have seen, the surviving teaching materials for the codification (Institutes, Digest, and Code) are in Greek. Some such also exist for the Novels. Both the surviving works which reflect collections of Novels from the 570s are in Greek (Theodore of Hermopolis, Athanasius of Emesa), at a time when, Beirut having already been destroyed in 551, even Constantinople had probably ceased to have a properly functioning law school following the death of Justinian. ${ }^{99}$ These provide summaries and, most usefully, cross-references to parallel complementary or divergent rulings, especially where these appear in the earlier codification.

The two works from the 550s are rather different. Both are in Latin. The first is the so-called Epitome of Julian, who was antecessor at Constantinople. ${ }^{100}$ This comprises his lecture course upon the Novels, essentially an extended index or set of paragraphai. There is some trace of Julianic materials in Greek in the Byzantine tradition, but, from these alone, we would not know that he had lectured in Latin. ${ }^{101}$ There also survive two short Latin treatises, perhaps for practitioners rather than students, associated with the Julianic corpus, intended to assist with finding the right sections in the vast array of the Justinianic materials, and which seem more the production of Constantinople than Rome or Ravenna. ${ }^{102}$

The second work is the Authenticum, a Latin set of Novels. ${ }^{103}$ For a long time, the true nature of the Authenticum was not appreciated. In the later Middle Ages it came to be regarded as Justinian's authoritative collection, despite its often inelegant Latin, and

\footnotetext{
99 The Breviarium of Theodore was based upon the Collection of 168 Novels (C. E. Zachariae von Lingenthal, Anekdota III (Leipzig 1843) 1-165). Athanasius must have worked from a different collection (Simon and Troianos, Novellensyntagma, n. 97, above).

${ }^{100}$ G. Hänel, Iuliani epitome latina Novellarum Iustiniani (Leipzig 1873); W. Kaiser, Die Epitome Iuliani. Beiträge zum römischen Recht im frühen Mittelalter und zum byzantinischen Rechtsunterricht (Frankfurt 2004).

${ }^{101}$ D. Simon et al., 'Zum griechischen Novellenindex des Antecessor Julian', in Fontes Minores II (Frankfurt 1977) 1-29.

${ }^{102}$ Dictatum de consiliariis, collectio de tutoribus: Liebs, Jurisprudenz (n. 94, above) 235-46; Kaiser, Epitome Iuliani (n. 100, above) 266-73.

${ }^{103}$ It provides the main Latin text of Schoell and Kroll, Corpus Iuris Civilis III (n. 93, above), but there is a stand-alone edition: G. E. Heimbach, Authenticum 2 vols (Leipzig, 1846-1851).
} 
was incorporated in the Bolognese Vulgate of the Corpus Iuris Civilis. ${ }^{104}$ Only in the twentieth century was it finally identified by Scheltema as consisting primarily of kata poda versions of the Greek Novels. ${ }^{105}$ Only for those Novels collected in Latin, such as that on senators (Nov. 62 = Auth. 64), did it preserve Justinian's originals. Their nature can be seen by giving as a short example the first sentence from the very first Novel, the Latin kata poda placed above the Greek original:

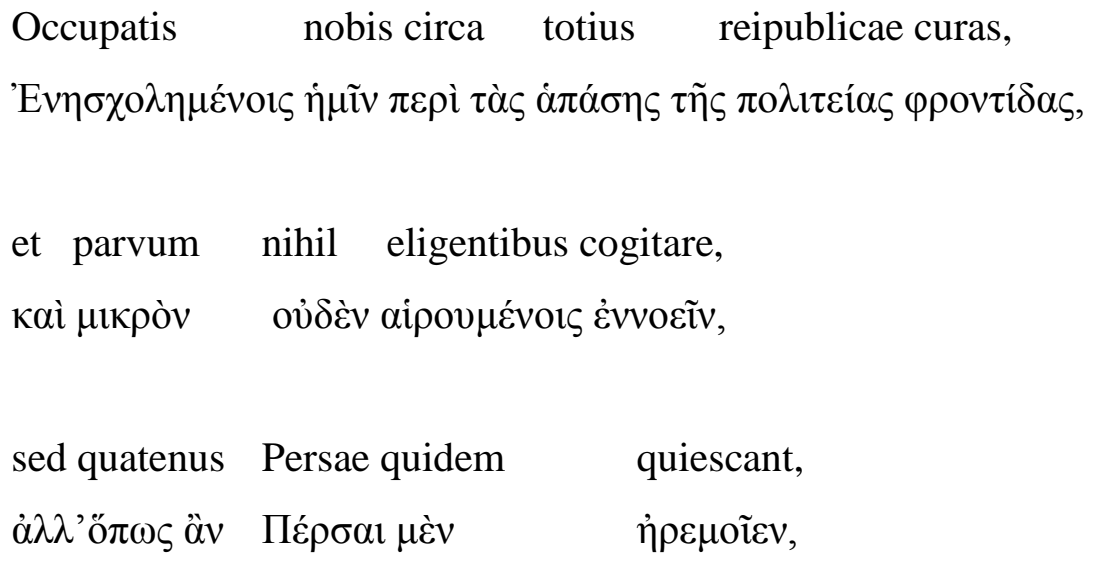

\begin{tabular}{|c|c|}
\hline Vandali vero & cum Mauris \\
\hline $\mathrm{B} \alpha \nu \delta i ́ \lambda o r ~ \delta \grave{\varepsilon}$ & 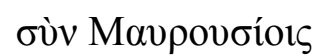 \\
\hline
\end{tabular}

Carchedonii autem antiquam recipientes habeant libertatem,

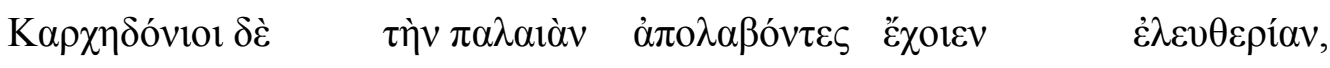
et Tzani nunc primum sub Romanorum facti republica

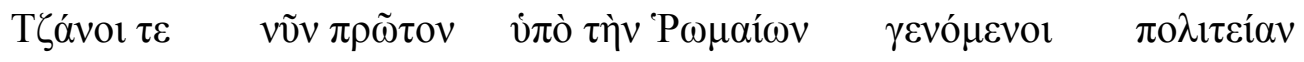
inter subiectos habeantur, quod nondum hactenus nisi

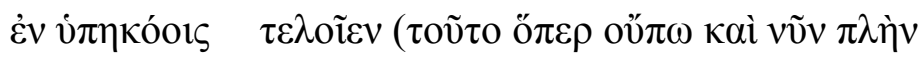

\footnotetext{
${ }^{104}$ The Creation of the Ius Commune: From Casus to Regula, eds. J. W. Cairns and P. J. du Plessis (Edinburgh 2010) 16-17.

${ }^{105}$ H. J. Scheltema, 'Subseciva XI: Das Authenticum', RHD 31 (1963) 275-79 (repr. Opera Minora (n. 36, above) 133-37).
} 


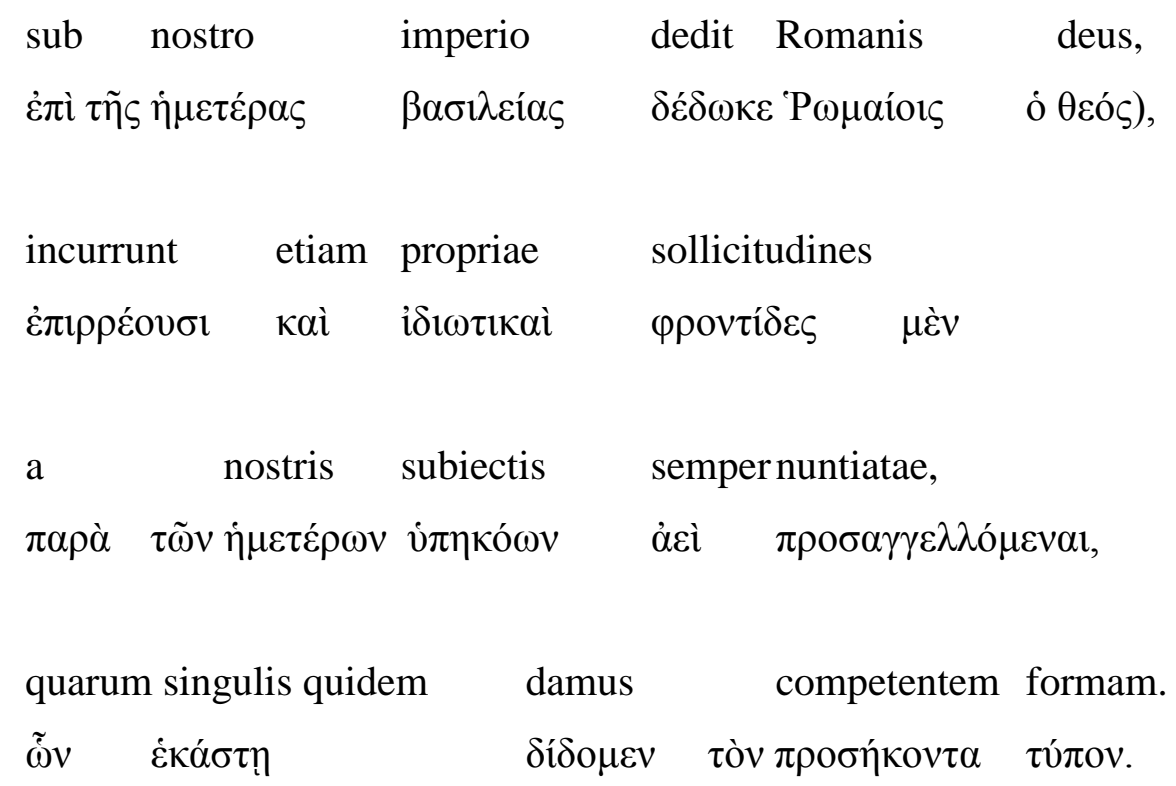

While we have been engaging our thoughts for the whole state and choosing to ponder no small matters, but how the Persians might quieten down, the Vandals with the Mauri be obedient, the Carthaginians may receive and keep their ancient freedom, and the Tzani may now for the first time come under the Roman state and be in subjection (this which god has given to the Romans never before now except under our reign), there rush upon us continually addressed by our subjects also private concerns, to each of which we are giving the appropriate solution.

Suddenly, therefore, we have evidence for teaching in Latin in Constantinople. This may reflect the needs of expatriate students from Italy and Africa, where there were no formal or only embryonic law schools. ${ }^{106}$ Of course, as the imperial capital, Constantinople probably always had a livelier Latin culture than anywhere else in the East. ${ }^{107}$ We must remember that we are at the mercy of our sources. We have some genuinely bilingual manuscripts from the sixth century, such as the Florentine Digest and the Verona Code palimpsest (noted above), but after the sixth century the traditions diverge quite quickly. The Byzantine legal materials are almost entirely in Greek.

\footnotetext{
${ }^{106}$ For recent discussion of early medieval law teaching in Rome, see L. Loschiavo, 'Was Rome still a centre of legal culture in the sixth to eighth centuries?', Rechtsgeschichte 23 (2015) 83-108.

${ }^{107}$ Averil Cameron, 'Roman studies in sixth-century Constantinople', in Transformations of Late Antiquity: Essays for Peter Brown, eds P. Rousseau and M. Papoutsakis (Farnham 2009) 15-36.
} 
Sometimes, however, in early medieval manuscripts the copyists, if being very careful, attempt to keep some terms or names in Latin script. ${ }^{108}$ The western materials by contrast are entirely in Latin. The Greek is dropped, and only rarely are there mangled attempts to copy Greek. ${ }^{109}$ The Ravenna Papyri (extending from the fifth to ninth centuries) contain no Greek documents, nor even Greek in documents, beyond some Latin subscriptions written in Greek letters. By contrast, some subscriptions are even in Gothic, although perhaps more ossified than living. ${ }^{110}$ The sixth century in Italy was, in fact, an era of translation from Greek to Latin, whether we consider the numerous texts of the so-called Ravenna medical school, ${ }^{111}$ or Cassiodorus's efforts at Vivarium with the Tripartite History and Jewish Antiquities. ${ }^{112}$ These, however, were texts intended to substitute for the originals, not facilitate direct engagement. The Justinianic codification being mainly in Latin was potentially usable already, even with the Greek ignored. This was less easy for the Novels, whose major collections, originating in the East, contained mostly constitutions in Greek. No official set of original Novels in Latin seems to have been sent to Italy, nor were individual enactments collected there on any scale. ${ }^{113}$ Even Justinian's Pragmatic Sanction reorganizing the civil government of Italy in 554 only exists as a summary annexed to the Epitome of Julian. ${ }^{114}$ Thus it was substitute Latin versions, either summaries or translations imported from Constantinople, that came to be copied and circulated. ${ }^{115}$ Indeed, Gregory the Great seems to have had to make (or have had made) his own version of one of the Novels (Nov. $90=$ Auth. 90), ${ }^{116}$ either because he possessed it only in Greek, or because he doubted the quality of some Authenticum-style

\footnotetext{
${ }^{108}$ Lokin, Theophili (n. 72, above) xxiii-xxvi.

109 See Corcoran, 'Codex of Justinian' (n. 10, above) cxli and 'Roman law in Ravenna' (n. 35, above) 179.

${ }^{110}$ Corcoran, 'Roman law in Ravenna' (n. 35, above) 183-84.

${ }^{111}$ Corcoran, 'Roman law in Ravenna' (n. 35, above) 181.

${ }^{112}$ Cassiod. Inst. 1.17.1, 2.pr.4 and 2.2; D. Scholten, 'Cassiodorus's Historia Tripartita before the earliest extant manuscripts', in The Resources of the Past in Early Medieval Europe, eds C. Gantner et al. (Cambridge 2015) 34-50; R. Pollard, 'Reading Josephus at Vivarium? Annotations and Exegesis in Early Copies of the Antiquities', Florilegium 30 (2013) 103-42; D. Levenson and T. Martin, 'The Ancient Latin Translations of Josephus', in A Companion to Josephus, eds H. H. Chapman and Z. Rodgers (Chichester 2016) 322-44.

${ }^{113}$ Corcoran, 'Roman law in Ravenna' (n. 35, above) 172.

${ }^{114}$ Justinian, Nov. App. VII (= Corpus Iuris Civilis III (n. 93, above) 799-802); also at Hänel, Iuliani Epitome (n. 100, above) 189-91.

${ }^{115}$ Corcoran, 'Roman law in Ravenna' (n. 35, above) 177-79.

${ }^{116}$ Greg. Reg. 13.49[50].
} 
kata poda. ${ }^{117}$ He certainly is vocal elsewhere in his criticism of literal word-for-word translation (in the case of his Latin letters translated in Constantinople), describing a process that managed at once to confound the sense and not even make the individual words intelligible. ${ }^{118}$ Although it is tempting to see this as a comment on the difficulties of communication in a world of declining Greek-Latin bilingual expertise in the 590s, this characterization can sometimes fit the legal kata poda - at least if they are viewed as self-standing translations, rather than crutches to enable the utilization of another language.

I have already said that no manuscript exists to demonstrate clearly how a kata podas translation was displayed. However, we do have a rather confused note, present in several manuscripts (and probably late antique in origin), which describes the nature of the late-antique bilingual manuscript that was the source text of the later Authenticum. ${ }^{119}$ The translation of this passage is not easy, as it attempts to compare the numeration difficulties between the Epitome of Julian and the Authenticum source collection. The key part reads:

Hae sunt que interpretate non sunt quas tantum in codice greco habemus (sunt autem et quedam latine inmixte grecis, que inter grecas tantummodo sunt, non etiam in presenti codice).

These are the [constitutions], which were not rendered [in the Epitome], which we have only in the Greek book; now there are also some Latin texts intermixed with

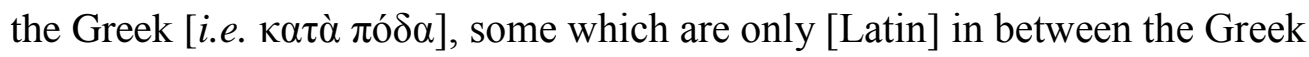
texts, also not in the current book [sc. Epitome]).

This seems to describe a Greek manuscript with two types of Latin text, one intermixed (thus the interlinear crib rather than parallel columns?), the other self-standing texts

\footnotetext{
117 Although Gregory sometimes protests ignorance of Greek (Reg. 7.29, 11.55), this is usually regarded as false modesty (J. R. C. Martyn, The Letters of Gregory the Great, 3 vols (Toronto 2004) I, 102-03).

Michael Crawford has suggested (pers. comment) that the Latin translation of Nov. 90 is Gregory's own.

${ }^{118}$ Greg. Reg. 7.27; cf. 1.28, 10.21 .

${ }^{119}$ L. Loschiavo, 'Il codex graecus e le origini del Liber authenticorum', ZRG 127 (2010) 115-71 (126, 165); Ms Escorial S.1.9, f. $155^{\mathrm{r}}$ (mid-twelfth century).
} 
scattered between the Greek ones. If this interpretation is correct, this is the closest we can come to visualizing a sixth-century interlinear kata poda manuscript.

The two language traditions diverged. Clearly under Justinian, highly competent legal professors and professionals were able to engage with both Greek and Latin, reading, interpreting, teaching, and composing. Thereby, they not only saved the Latin corpus of Roman law in the long term, but also developed a fixed legal vocabulary in Greek. Yet, the wide range of Greek teaching materials, including the kata poda crib, could enable a Greek-speaking student at say, Beirut, who then became a practising advocate, to survive on very little Latin, provided he learnt enough of the technical terminology, which could even be naturalized by transcription into Greek, if necessary. We only need think of the advocate Dioscorus of Aphrodito, notorious for his Greek poetry, but competent in many other ways, who acquired a good legal education, probably shortly after the introduction of the codification in the late 530s/early 540s, without apparently attending either of the official law schools (Constantinople, Beirut) and taking their full five-year course, probably training in Alexandria. ${ }^{120} \mathrm{He}$ seems to have survived very well with minimal Latin, although capable of using a few technical terms occasionally written in Latin script. ${ }^{121}$ When petitioning the imperial court, he even sent draft texts of rescripts in the form he hoped to receive back. ${ }^{122}$ Although he cites imperial legislation, it is far from clear that he was reading the Code in Latin, although I am sceptical that his citation of an apparently unattested passage of Leo is evidence of his reliance upon a pre-Justinian version in Greek. ${ }^{123}$ Still, he is confident enough to invoke imperial laws for his purpose, irrespective of the gap between their original language and his knowledge.

Bilingualism, of course, is not simply about being equally at home in two languages and can come in many forms, ${ }^{124}$ as must have been true for Dioscorus and the

\footnotetext{
${ }^{120}$ See L. S. B. MacCoull, Dioscorus of Aphrodito: his work and his world (Berkeley 1988) 9.

${ }^{121}$ MacCoull, Dioscorus (n. 120, above) 51.

${ }^{122}$ P. van Minnen, 'Dioscorus and the law', in Learned Antiquity: Scholarship and Society in the Near East, the Greco-Roman World, and the Early Medieval West, eds A. A. MacDonald et al. (Leuven 2003) 115-33.

${ }^{123}$ P. Cair. Masp. I 67028 (M. Amelotti and L. Migliardi Zingale, Le costituzioni giustinianee nei papiri e nelle epigrafi, $2^{\text {nd }}$ ed. [Milan 1985] 56-59). The law of Leo relevant for his case seems to be CJ 5.9.6.

${ }^{124}$ See, e.g., A. Mullen, 'Latin and other languages: societal and individual bilingualism', in A Companion to the Latin Language, ed. J. Clackson (Malden, MA - Oxford 2011) 527-48.
} 
many students and practitioners of law in the eastern part of the Empire. True 'balanced' bilinguals may have been rare in Justinian's empire, even among lawyers. The fact that Justinian's formidable normative corpus existed overwhelmingly in Latin is something of a linguistic mirage and, indeed, it is perhaps fortunate that such an ambitious project drawing primarily on Latin texts was accomplished at the time it was, since it is unlikely to have been practical if attempted a generation or two later. Outside the capital and across the East, legal practice was effectively able to survive on Greek alone, and the very teaching materials designed to impart knowledge of the Latin corpus enabled its supersession.

Newcastle University 